\title{
Pembelajaran Sekolah Unggulan Di Masa Pandemi Covid-19 (Studi Tentang Manajemen Pembelajaran di Sekolah Menengah Atas Islam Terpadu Hidayah Klaten)
}

\author{
${ }^{1 *}$ Kelik Wardiyono, ${ }^{2}$ Siti Choiriyah, ${ }^{3}$ Wasis Pambudi \\ ${ }^{1}$ Mahasiswa Magister Manajemen Pendidikan Islam IAIN Surakarta \\ 2Institut Agama Islam Negeri Surakarta \\ ${ }^{3}$ SMAIT Hidayah Klaten \\ 1*klik.wouw@gmail.com, ${ }^{2}$ sitichoiriyah2009@yahoo.co.id, ${ }^{3}$ wasisabuifa@gmail.com
}

\begin{abstract}
Abstrak: Covid-19 berimplikasi dalam berbagai lini kehidupan masyarakat dunia. Satu diantaranya adalah bidang pendidikan. Sekolah di Indonesia "khususnya" dan dunia pada umumnya tidak berlaku pembelajaran tatap muka guna meminimalisir dampak yang akan ditimbulkan dari pandemi global tersebut. Pembatasan kerumuman, berkumpulnya banyak orang dalam satu tempat serta patuh terhadap protokol kesehatan menjadi sebuah keharusan. Studi ini menyelidiki bagaimana sekolah menyikapi kebijakan dan kondisi yang berkepanjangan ini. Sekolah unggulan SMAIT Hidayah Klaten merupakan satu diantara sekolah yang terdampak serius terhadap kondisi dan kebijakan terkait. Hasil penelitian menunjukkan bahwa SMAIT Hidayah Klaten sangat adaptif terhadap kebijakan pemerintah terkait proses pembelajaran di masa covid19. Setidaknya, manajemen pembelajaran dilakukan kombinasi dalam jaringan dan pembelajaran luar jaringan yang kemudian konsep ini diberi nama "DAR-LING". Konsep ini bertumpu pada 3 prinsip yaitu daring sebagai ekosistem, school visit dan home visit.
\end{abstract}

Kata kunci : Pembelajaran, Covid-19, School Visit, Home Visit.

\begin{abstract}
Covid-19 brings implications in various aspects of life for the world community, one of which is education. Schools in Indonesia "in particular" and the world in general do not apply face-to-face learning to minimize the impacts that will be caused by the global pandemic. Restricting the crowd, gathering of many people in one place, and adhering to health protocols are imperative. This study investigates how schools respond to this prolonged policy and condition. SMAIT Hidayah Klaten is one of the top schools that is seriously affected by the conditions and related policies. The results of the study suggest that SMAIT Hidayah Klaten is very adaptive to government policies regarding the learning process during the Covid-19 period. At least, learning management is carried out by a combination of online and offline learning named "DAR-LING". This concept rests on 3 principles, namely online as an ecosystem, school visit and home visit.
\end{abstract}

Keywords : Learning, Covid-19, School Visit, Home Visit.

\section{PENDAHULUAN}

Fenomena Covid-19 diawali dengan adanya kasus pasien pneumonia kolektif akibat infeksi virus Corona jenis baru. Virus baru ini termasuk dalam coronavirus jenis beta, yang memiliki selubung dan berbentuk bulat atau oval, biasanya polimorfik, dan berdiameter 60-140 nm. Karakteristik genetiknya sangat berbeda dengan SARSr-CoV dan MERSr-CoV. Penelitian saat ini menunjukkan bahwa ia memiliki lebih dari 85\% homologi dengan virus korona mirip SARS kelelawar (kelelawar-SL-CoVZC45). Baru-baru ini, Komisi Klasifikasi Virus Internasional mengajukan proposal bernama novel coronavirus sebagai "SARS-CoV-2", dan 
Organisasi Kesehatan Dunia secara resmi menamai novel coronavirus pneumonia sebagai "COVID-19"1. Covid-19 dengan cepat menyebar ke berbagai negara. WHO menetapkan Covid-19 sebagai Public Health Emergency of International Concern (PHEIC)/ Kedaruratan Kesehatan Masyarakat yang Meresahkan Dunia (KKMMD) pada tanggal 30 Januari 2020 dan menetapkan Covid-19 sebagai pandemi pada tanggal 11 Maret 2020. Indonesia pertama kali melaporkan 2 kasus konfirmasi Covid-19 pada 2 Maret 2020. Data terakhir per tanggal 21 Oktober 2020 versi Worldometer mencatat ada 215 negara terjangkit virus dengan jumlah kasus sebanyak 41.168.630. Dari angka tersebut, telah terjadi 1.131.312 kasus kematian dan 30.701.165 pasien dinyatakan sembuh ${ }^{2}$. Update data terbaru di Indonesia pada tanggal yang sama bersumber data Satuan Tugas Penanganan Covid-19, terdapat 373.109 kasus positif, 297.509 dinyatakan sembuh dan 12.857 dinyatakan meninggal dunia ${ }^{3}$.

Keberadaan Covid-19 berdampak pada seluruh sendi kehidupan. Sendi ekonomi berubah karena adanya program Work From Home dan sendi sosial berubah karena adanya Social distancing dan Physical distancing. Pendidikan termasuk aspek yang terdampak, dengan adanya kebijakan Belajar Dari Rumah (BDR) atau Pembelajaran Jarak Jauh (PJJ). Kementerian Pendidikan dan Kebudayaan Republik Indonesia menerbitkan Surat Edaran nomor 4 tahun 2020 tanggal 24 Maret 2020 tentang Pelaksanaan Kebijakaan Pendidikan Dalam Masa Darurat Covid-19, diantara isinya adalah mengharuskan siswa belajar dari rumah dan meniadakan Ujian Nasional.

Menteri Pendidikan dan Kebudayaan bersama Menteri Agama, Menteri Kesehatan, dan Menteri Dalam Negeri mengeluarkan Surat Keputusan Bersama (SKB) tanggal 15 Juni 2020 tentang Panduan Penyelenggaraan Pembelajaran Pada Tahun Ajaran 2020/2021 dan Tahun Akademik 2020/2021 di Masa Pandemi Corona Virus Disease 2019 (Covid-19) yang isinya yaitu awal tahun pelajaran ditetapkan tanggal 13 Juli 2020, Satuan pendidikan yang berada di daerah zona hijau dapat melakukan pembelajaran tatap muka di satuan pendidikan setelah mendapatkan izin dari pemerintah daerah melalui dinas pendidikan provinsi atau kabupaten/kota, kantor wilayah Kementerian Agama provinsi, dan kantor Kementerian Agama kabupaten/kota sesuai kewenangannya berdasarkan persetujuan gugus tugas

${ }^{1}$ Jingkang Zhu \& Tao Xu Xian Zhou, "Clinical Characteristics of Coronavirus Disease 2019 (COVID-19) Patients with Hypertension on Renin-Angiotensin System Inhibitors," Clinical and $\begin{array}{llllll}\text { Experimental Hypertension } & 42, & \text { no. } & 7 & \text { (2020): } & 656-60 \text {, }\end{array}$ https://doi.org/10.1080/10641963.2020.1764018.

2 "Reported Cases and Deaths by Country, Territory, or Conveyance," n.d., https://www.worldometers.info/coronavirus/ .

3 Satuan Tugas Penanganan COVID-19, "Situasi Virus COVID-19 Di Indonesia," n.d., https://covid19.go.id. 
percepatan penanganan COVID-19 setempat. Satuan pendidikan yang berada di daerah zona kuning, oranye dan merah, dilarang melakukan proses pembelajaran tatap muka di satuan pendidikan dan tetap melanjutkan kegiatan Belajar Dari Rumah (BDR).

Kebijakan dan aturan-aturan tersebut meniscayakan sekolah harus berusaha keras untuk mencari model pembelajaran alternatif yang berbeda dengan pembelajaran tatap muka sebelum pandemi Covid-19. Pembelajaran online merupakan salah satu alternatif tersebut. Menurut Moore, Dickson-Deane, \& Galyen ${ }^{4}$ Pembelajaran online merupakan pembelajaran yang menggunakan jaringan internet dengan aksesibilitas, konektivitas, fleksibilitas, dan kemampuan untuk memunculkan berbagai jenis interaksi pembelajaran. Pembelajaran online dalam pelaksanaannya memerlukan perangkat berupa ponsel pintar/gawai, tablet atau laptop dan jaringan internet. Beberapa media dan aplikasi digunakan dalam pembelajaran online, diantaranya Google Classroom, Edmodo, dan Schoology5, dan applikasi pesan instan seperti WhatsApp ${ }^{6}$. Media sosial seperti Facebook dan Instagram juga dapat dipakai dalam pembelajaran online ${ }^{7}$.

Pembelajaran online yang dilakukan bukan tanpa kendala. Fieka Nurul Arifa ${ }^{8}$ menyebutkan hambatan yang dihadapi dalam pelaksanaan Pembelajaran Jarak Jauh (PJJ) antara lain berkaitan dengan kesiapan sumber daya manusia, kurang jelasnya arahan pemerintah daerah, belum adanya kurikulum yang tepat, dan keterbatasan sarana dan prasarana, khususnya dukungan teknologi dan jaringan internet. Kesiapan sumber daya manusia meliputi pendidik (guru dan dosen), peserta didik, dan dukungan orang tua merupakan bagian terpenting dalam pelaksanaan PJJ. Banyak keluhan baik dari pendidik, peserta didik, maupun orang tua terkait pelaksanaan belajar dari rumah. Banyak pendidik yang mengeluhkan terbatasnya

${ }^{4}$ Joi L. Moore, Camille Dickson-Deane, and Krista Galyen, "E-Learning, Online Learning, and Distance Learning Environments: Are They the Same?," The Internet and Higher Education 14, no. 2 (March 2011): 129-35, https://doi.org/10.1016/j.iheduc.2010.10.001.

${ }^{5}$ M. A. S Enriquez, "Students Perceptions on the Effectiveness of the Use of Edmodo as a Supplementary Tool for Learning," in DLSU Research Congress, 2014; S. Iftakhar, "Google Classroom: What Works And How?," Journal of Education and Social Sciences, 2016; A. S. Sicat, "Enhancing College Students Proficiency in Business Writing Via Schoology," International Journal of Education and Research, 2015.

${ }^{6}$ Simon So, "Mobile Instant Messaging Support for Teaching and Learning in Higher Education," The Internet and Higher Education 31 (October 2016): https://doi.org/10.1016/j.iheduc.2016.06.001.

7 Vikas Kumar and Pooja Nanda, "Social Media in Higher Education," International Journal of Information and Communication Technology Education 15, no. 1 (January 2019): 97-108, https://doi.org/10.4018/IJICTE.2019010107.

${ }^{8}$ Fieka Nurul Arifa, Tantangan Pelaksanaan Kebijakan Belajar Dari Rumah Dalam Masa Darurat Covid-19 (Jakarta: Pusat Penelitian Badan Keahlian. DPR RI, 2020). 
ketersediaan sarana teknologi, kemampuan pengoperasian maupun keterbatasan jaringan internet di beberapa daerah.

Komisi Perlindungan Anak Indonesia (KPAI) menerima sekitar 213 pengaduan Pembelajaran Jarak Jauh, baik dari orang tua maupun siswa yang terjadi dalam rentang waktu 16 Maret sampai dengan 9 April 20209. Pengaduan tersebut berkaitan dengan penugasan yang terlalu berat namun waktunya singkat, tugas merangkum dari buku yang terlalu banyak, jam belajar masih belum fleksibel, kurangnya kuota dan keterbatasan kepemilikan gawai sehingga siswa tidak dapat mengikuti ujian dalam jaringan.

Keadaan krisis karena Covid-19 menyebabkan ancaman yang serius terhadap proses pendidikan dan pembelajaran yang dilakukan sekolah. Jika tidak dikelola dengan baik, pembelajaran yang dilakukan oleh para guru sekolah akan semakin tidak bermakna dan menjauh dari tujuan kebermaknaan pendidikan sebagaimana amanat Surat Edaran Menteri Pendidikan dan Kebudayaan RI no 4 tahun 2020. Di sisi lain, proses pembelajaran di sekolah merupakan alat kebijakan publik terbaik sebagai upaya peningkatan pengetahuan dan skill ${ }^{10}$. Pembelajaran sekolah dapat meningkatkan pengetahuan, keterampilan sosial dan kesadaran kelas sosial siswa. Sekolah secara keseluruhan adalah media interaksi antar siswa dan guru untuk meningkatkan kemampuan inteligensi, skill dan rasa kasih sayang diantara mereka. Tetapi sekarang kegiatan yang bernama sekolah berhenti dengan tiba-tiba karena gangguan Covid-19. Manajemen lembaga pendidikan/sekolah dalam merencanakan, mengorganisasikan, melaksanakan, dan melakukan pengontrolan /pengawasan pembelajaran menjadi hal urgen dan prioritas.

Fokus tulisan ini adalah manajemen pembelajaran di SMAIT Hidayah Klaten selama masa pandemi Covid-19. Tujuannya adalah untuk mendapatkan gambaran manajemen pembelajaran sekolah dalam menghadapi pandemi Covid-19 yang meliputi perencanaan (planning), pengorganisasian (organizing), penggerakan/pelaksanaan (actuating) dan pengawasan (controlling). Sekolah ini dipilih karena baru berdiri pada tahun 2017 sehingga dalam menghadapi pandemi Covid-19 ini harus memberikan layanan pembelajaran yang baik agar tetap eksis dan diminati oleh masyarakat serta mendapatkan hasil pendidikan yang baik bagi para siswanya.

9 "KPAI Terima 213 Aduan Soal Pembelajaran Jarak Jauh," n.d., https://republika.co.id/berita/q8q6oq354/kpai-terima-213-aduan-soal-pembelajaran-jarak-jauh. .

${ }_{10}$ Aji R, "Dampak Covid-19 Pada Pendidikan Di Indonesia: Sekolah, Keterampilan, Dan Proses Pembelajaran," SALAM: Jurnal Sosial Dan Budaya Syar-I 7, no. 5 (April 14, 2020): 395-402. 


\section{PEMBAHASAN}

Konsep perencanaan pembelajaran SMAIT Hidayah Klaten memadukan antara pembelajaran dalam jaringan dan pembelajaran luar jaringan yang kemudian konsep ini diberi nama "DAR-LING". Konsep ini bertumpu pada 3 prinsip yaitu Daring sebagai ekosistem, School Visit dan Home Visit. Ekosistem besar dari Metode "Dar-Ling" tetaplah pembelajaran daring (online) yang sering disebut dengan Belajar Dari Rumah (BDR) atau Pembelajaran Jarak Jauh (PJJ), tapi di dalamnya terdapat inovasi dan kreasi yang memungkinkan terjadi pertemuan siswa dengan gurunya untuk tujuan memotivasi siswa, menguatkan ruhiyah dan semangat siswa agar terus dalam kondisi yang baik, dan tentunya dengan mekanisme dan protokol khusus.

Kepala SMAIT Hidayah Klaten menjelaskan tentang rencana pembelajaran "DarLing" selama masa pandemi Covid-19 bahwa dalam konsep Pembelajaran "Dar-Ling" ini, pembelajaran daring (BDR atau PJJ) tetaplah menjadi lingkungan besar yang menaungi, tapi isinya tidak melulu seratus persen online, yang makin lama dirasa makin membosankan oleh siswa. Karena sehebat-hebatnya perangkat online tidaklah akan bisa menggantikan "ruh" kehadiran guru di hadapan siswa. Daring berfungsi sebagai sistem penyangga yang akan membungkus aktivitas komponen-komponen lain di dalamnya. Dengan payung besar tetap daring ini, harapannya akan menenangkan banyak orang karena secara umum masih sesuai dengan kebijakan yang dikeluarkan pihak terkait, walaupun di dalamnya memang terdapat kreasi dan inovasi yang tetap memprioritaskan kesehatan ${ }^{11}$.

Dari hasil wawancara, survey dan observasi yang dilakukan penulis serta analisis data dari telaah dokumen yang ada penelitian ini mengantarkan kepada beberapa temuan. Pertama, permasalahan yang dihadapi orangtua saat pembelajaran daring: minimnya pendampingan orang tua karena orangtua bekerja $75.8 \%$; ketiadaan perangkat daring $(\mathrm{hp})$ untuk siswa $13.1 \%$ dan keberatan dalam pembelian paket data 11.1\%. Kedua, efek pembelajaran daring yang diperpanjang dalam pandangan orang tua: siswa tidak terkendali $45.5 \%$; kebosanan siswa 38.4\%; perhatian kurang $12.1 \%$ dan siswa tambah kreatif dan mandiri $4 \%$.

Analisis yang penulis lakukan terhadap perencanaan (planning) pembelajaran selama masa pandemi Covid-19 di SMAIT Hidayah Klaten ini nampaknya selaras dengan manajemen krisis terutama pada tahap "During the Crisis" dimana manajemen sekolah dilakukan dengan melibatkan pihak-pihak yang bisa diajak untuk menangani krisis yang terjadi yang berupa tindakan menganalisa latar belakang terjadinya krisis, menemukan masalah jangka pendek dan jangka panjang, mencari dan menunjukkan informasi yang relevan dalam penanganan krisis, dalam hal ini pandemi Covid-19.

11 wawancara Kepala Sekolah pada hari Kamis, 15 Oktober 2020 
Aktor dan pemimpin utama dalam penanganan krisis ini adalah kepala sekolah ${ }^{12}$. Alihalih dari hasil penelitian-penelitian yang lain, beberapa lembaga pendidikan menerapkan konsep pembelajaran dalam jaringan/online murni, misalnya di Sekolah Dasar $^{13}$, pembelajaran di Perguruan Tinggi Islam ${ }^{14}$ atau bahkan di Universitas Terbuka ${ }^{15}$. SMAIT Hidayah Klaten merencanakan pembelajaran selama masa pandemi dengan mengkombinasikan pembelajaran dalam jaringan dan luar jaringan. Pembelajaran dengan pola seperti ini adalah sesuatu yang unik dan memungkinkan siswa mendapatkan layanan pendidikan yang bervariatif dan relatif lebih baik dibandingkan dengan pembelajaran dalam jaringan murni di sekolah lain. Dalam perspektif manajemen pembelajaran dar-ling di SMAIT Hidayah Klaten dapat dijabarkan sebagai berikut:

\section{Pembelajaran "Dar-Ling"}

Pengorganisasian pembelajaran "Dar-Ling" di SMAIT Hidayah Klaten dilakukan dengan pembagian wilayah kerja sesuai dengan pola yang akan dilakukan, yaitu Pembelajaran Daring, School Visit dan Home Visit. Sejak awal perencanaannya, pembelajaran di masa pandemi melibatkan semua guru, wali kelas dan pengampu tahfidz dalam konsep “Dar-Ling” ini, dengan harapan agar konsep pembelajaran yang merupakan kombinasi dari pembelajaran dalam jaringan dan luar jaringan dapat berjalan dengan baik. Hal ini karena program Daring ada beberapa kegiatan, begitu juga program Luring juga ada kegiatan School Visit dan Home Visit. Silahkan anda explore data dan dokumen yang ada di bagian kurikulum.

Pengorganisasian pembelajaran selama masa pandemi Covid-19 melibatkan semua guru dan wali kelas serta pengampu tahfidz. Pelibatan ini sesuai dengan jenis pembelajaran, tupoksi dan arahan bapak kepala sekolah. Pembelajaran Daring sebagai sebuah ekosistem, terdiri atas mutabaah yaumiyah dan tahfidzul quran, bina pribadi Islami, Pengembangan karakter dan skill serta pembelajaran daring itu sendiri. Tiga hal pertama yang saya sebut

${ }^{12}$ Ali Murfi et al., "Kepemimpinan Sekolah Dalam Situasi Krisis Covid-19 Di Indonesia," MANAGERIA: Jurnal Manajemen Pendidikan Islam 5, no. 1 (June 4, 2020): 119-36, https://doi.org/10.14421/manageria.2020.51-07.

13 Wahyu Aji Fatma Dewi, "Dampak COVID-19 Terhadap Implementasi Pembelajaran Daring Di Sekolah Dasar," EDUKATIF: JURNAL ILMU PENDIDIKAN 2, no. 1 (April 29, 2020): 55-61, https://doi.org/10.31004/edukatif.v2i1.89.

14 Wahyu Hidayat Yaya Suryana, Hary Sanusi Priatna, A. Heris Hermawan, "Manajemen Pembelajaran Daring Berbasis Empati Untuk Pemeliharaan Motivasi Belajar Daring Mahasiswa Dalam Situasi Wabah Covid-19," in Penulisan Karya Tulis Ilmiah UIN Sunan Gunung Djati Bandung Di Masa Work From Home Tahun 2020, 2020, http://digilib.uinsgd.ac.id/view/creators/Sanusi=3AHary_Priatna=3A=3A.html .

15 B. Khasanah, D. R. A. U., Pramudibyanto, H., \& Widuroyekti, "Pendidikan Dalam Masa Pandemi Covid-19," .. Jurnal Sinestesia 10, no. 1 (2020): 41-48. 
tadi dilaksanakan oleh ustadz dan ustadzah yang memiliki kemampuan spesifik, sedangkan satu hal terakhir yaitu pembelajaran daring dilakukan dengan menyederhanakan kurikulum dan mengurangi tugas yang diberikan kepada siswa, tentunya dalam hal ini pelaksananya adalah para guru mapel. Sedangkan pembelajaran luar jaringan yang terdiri atas school visit dan home visit berkolaborasi baik guru tahfidz, wali kelas, tim guru, tim kesiswaan, tim kurikulum bahkan bapak kepala sekolah.

Pembelajaran Daring sebagai Ekosistem dilakukan dengan menitikberatkan kepada kebermaknaan belajar dan pembentukan karakter Islami. Beberapa program kerja yang dirumuskan dalam kelompok pembelajaran daring ini adalah mutabaah yaumiyah dan tahfidzul Quran. Program ini dilakukan dengan aplikasi Google Form yang berisi tagihan amal ibadah harian. Siswa mengisi dan mengirimkan data setiap hari sesuai dengan capaian yang didapatkan. Pembelajaran tahfidzul Quran dilakukan dengan video call atau voice note/Whats App dengan pola menambah hafalan 1 ayat per hari dan murojaahnya. Seorang ustadz/ustadzah mengampu 5-8 orang siswa. Sementara Bina Pribadi Islam. Program ini direncanakan dengan aplikasi google meet karena memungkinkan pertemuan virtual secara interaktif. Setiap pengampu mempunyai 6-10 siswa berdasarkan kelas dan dilaksanakan sepekan sekali sesuai dengan kesepakatan antara pengampu dan siswa. Adapun, pengembangan karakter dan skill siswa. Program ini merupakan program yang dilakukan siswa di rumah untuk menumbuhkan dan meningkatkan karakter dan skill, Pengelolaan program ini terintegrasi dengan sistem Dar-Ling yang dilaksakan dengan tujuan siswa terbentuk karakter dan meningkat skill sesuai yang ditetapkan. Pendidikan Karakter dan peningkatan skill yang ditetapkan diantaranya dapat ditampilkan dalam tabel berikut:

Tabel 1. Pendidikan Pengembangan Karakter Dan Skill

\begin{tabular}{|c|c|}
\hline Penguatan Karakter & $\tan$ Skill \\
\hline $\begin{array}{l}\text { - Keimanan dan ketakwaan kepada Allah swt, } \\
\text { melalui kegiatan evaluasi ibadah harian dan } \\
\text { Tahfidzul Quran } \\
\text { - Kejujuran dalam melaporkan mutabaah } \\
\text { yaumiyah dan pengerjaan tugas } \\
\text { - Berbakti keapada orang tua, melalui kegiatan } \\
\text { membantu pekerjaan rumah harian } \\
\text { - Peduli sesama, melalui kegiatan berperan serta } \\
\text { aktif membantu masyarakat sekitar rumah, } \\
\text { terutama bagi mereka yang sangat terdampak }\end{array}$ & $\begin{array}{l}\text { - Kemampuan dalam mengoprasikan } \\
\text { aplikasi atau software IT dalam } \\
\text { pembelajaran } \\
\text { - Keterampilan memasak, melalui } \\
\text { upload tugas memasak ke medsos dan } \\
\text { menandai akun sekolah } \\
\text { - Kemampuan mengolah barang bekas } \\
\text { menjadi lebih berharga melalui } \\
\text { penugasan berbasis proyek } \\
\text { - Kemampuan dalam menggunakan }\end{array}$ \\
\hline
\end{tabular}




\begin{tabular}{|c|c|}
\hline Penguatan Karakter & Peningkatan Skill \\
\hline $\begin{array}{l}\text { kehidupannya akibat pandemi Covid-19 } \\
\text { - Gotong royong dan bekerjasama, melalui } \\
\text { kegiatan penugasan di tengah kelompok } \\
\text { masyarakat melalui karang taruana, TPA, } \\
\text { kegiatan } \\
\text { setempat. }\end{array}$ & $\begin{array}{l}\text { camera dengan baik dan melakukan } \\
\text { video editing melalui tugas membuat } \\
\text { video tertentu } \\
\text { - Keterampilan melakukan branding, } \\
\text { melalui kegiatan branding sekolah } \\
\text { lewat seluruh akun medsos yang } \\
\text { dimiliki siswa }\end{array}$ \\
\hline
\end{tabular}

Sumber: Dokumen SMAIT Hidayah, diambil 21 Oktober 2020

Pembelajaran Daring diorganisasikan dengan cara penyederhanaan kurikulum dan pengurangan jam pelajaran. Penyederhanaan kurikulum dilakukan dengan memberikan KD prioritas sesuai mapel masing-masing. Penugasan juga dilakukan pengurangan dengan cara penugasan terintegrasi beberapa mapel, misalnya tugas Biologi kelas X, membuat laporan observasi lapangan tentang komponen biotik dana biotik di lingkungan sawah sekitar rumah, isi dari laporannya digunakan oleh mata pelajaran Biologi, sedangkan tata tulis laporannya digunakan untuk tugas Bahasa Indonesia. Beberapa aplikasi yang dipakai dalam pembelajaran dalam jaringan adalah grup whatsapp sebagai aplikasi utama koordinasi, google classroom sebagai sarana pengaturan pembelajaran, google meet sebagai sarana pembelajaran interaktif google form sebagai sarana evaluasi pembelajaran, you tube sebagai penampil video pembelajaran serta website sekolah dengan fitur tambahan e-learning, sebagai sarana pendukung.

Langkah-langkah pelaksanaan konsep "Dar-Ling". Penulis berkesimpulan bahwa langkah-langkah tersebut adalah: Penyiapan dan Pra-kondisi sekolah untuk penerapan konsep "Dar-Ling" yakni menggabungkan antara pembelajaran dalam jaringan dan luar jaringan dalam satu ekosistem, sehingga pemenuhan prasayarat daring dan luring menjadi hal yang harus dipenuhi sekolah. Kegiatan-kegiatan yang dilaksanakan dalam rangka penyiapan dan pra kondisi untuk penerapan konsep "Dar-Ling" ini adalah (a) Membentuk tim Gugus Tugas Covid-19 sejak Mei 2020 yang terus bekerja menyiapkan segala sesuatunya dalam penanganan penanggulangan penyebaran Covid-19 pada satuan pendidikan; (b) Sekolah mewajibkan guru dan karyawan untuk masuk (Work From Office/WFO) setiap hari kerja (Senin-Sabtu) mulai pukul 07.00 13.00 WIB sejak tanggal 13 Juli 2020 (c) Sekolah memenuhi fasilitas dalam rangka pelaksanaan protokol kesehatan dengan menyediakan wastafel lengkap dengan sabun cuci tangan di depan setiap kelas, melakukan penyemprotan desinfektan, pembelian masker cadangan, pembagian face shield kepada guru, 
karyawan dan siswa, thermogun dan penempelan poster himbauan dan prosedur kesehatan; (d) melakukan komunikasi dengan pihak terkait, seperti yayasan, komite sekolah, fasilitias kesehatan/Puskesmas dan atau Dinas Pendidikan serta (e) melakukan sosialisasi tentang pembelajaran melalui moda dalam jaringan/online. Sosialisasi dilakukan dengan pembuatan video maupun dengan mengadakan webinar. Contoh sosialisasi dengan video diantaranya dengan sosialisasi prosedur School Visit di laman You Tube dengan alamat https://www.youtube.com/watch?v=abUYIw_qH2I\&t=30s. Sedangkan contoh Webinar dengan judul SMAHIKA MENYAPA.

Analisis pelaksanaan pembelajaran SMAIT Hidayah Klaten selama masa pandemi Covid-19 yang mengkombinasikan pembelajaran daring dan luring merupakan ide kreatif dan inovatif, sekaligus "mengambil resiko yang lebih tinggi" jika penulis bandingkan dengan pembelajaran daring murni yang dilakukan oleh sekolah lain di Klaten. Pembelajaran yang inovatif dalam menyajikan pembelajaran online yang menghadapkan siswa pada berbagai pengalaman belajar akan menambah efektifitas pembelajaran online ${ }^{16}$. Pemberian kewenangan yang luas sesuai tugas pokok dan fungsinya oleh kepala sekolah dan waka kurikulum kepada guru menempatkan guru yang berfungsi sebagai designer, manager, dan sekaligus evaluator pembelajaran yang diasuhnya ${ }^{17}$. Menurut Bruce Joice: "tidak ada satupun model pengajaran yang bisa menggantikan model pengajaran lain pada satu waktu" 18 Artinya tetap dibutuhkan model pengajaran atau pembelajaran tertentu yang tepat untuk situasi tertentu seperti pada saat situasi covid-19. Bisa jadi yang lebih tepat modelnya menggunakan media Whats app ${ }^{19}$.

Pengawasan (Controlling) Pembelajaran SMAIT Hidayah Klaten selama Masa Pandemi Covid-19 dilakukan oleh kepala sekolah dan wakil kepala bagian kurikulum. Pengawasan dilakukan dengan tiga mekanisme, yaitu dengan observasi/pengamatan, wawancara dan kuesioner.

\section{School Visit}

School Visit adalah konsep kunjungan ke sekolah di sela-sela pembelajaran daring dari rumah dengan menerapkan protokol kesehatan yang ketat. School

16 Brozik D Zapalska A, Learning Styles and Online Education, 2006.

17 Mahmud, "Sosiologi Pendidikan" (Bandung: Pustaka Setia, 2012) .117.

${ }^{18}$ E. Joyce, B., Weil, M., \& Calhoun, Models of Teaching: Model-Model Pengajaran, ed. Ahmad Fawaid dan Ateilla Mirza (Yogyakarta: Pustaka Pelajar, 2009).. xviii.

19 Wijaya A, "Students Responses Toward The Use Of Whatsapp In Learning," Teaching and Learning English in Multicultural Contexts (TLEMC) 2, no. 1 (2018). 47. 
Visit dalam pengorganisasiannya lebih ditekankan pada fungsi "piknik jiwa", mengembalikan semangat siswa dengan cara mengunjungi sekolah dan mendapat motivasi dari para guru. Apalagi kecenderungan siswa selama pandemi Covid-19 dalam kondisi lonely (kesepian), ruhiyahnya garing, semangatnya down, maka School Visit diharapkan mampu membangkitkan semangat siswa kembali. Bisa dengan motivasi dan model sharing dengan pihak sekolah.

Setiap rombel dijadwalkan tiga pekan sekali menghadiri School Visit, dengan durasi kunjungan hanya berlangsung selama 2 jam tanpa istirahat di luar ruangan. Dan dalam satu hari jadwal School Visit hanya terdapat satu rombongan belajar yang datang mengunjungi sekolah. Dengan jumlah siswa terkecil 21 siswa dan terbanyak 26 siswa. Jumlah siswa dalam rombel tersebut kemudian dibagi ke dalam empat ruangan, sehingga setiap ruangan hanya terdapat maksimal 5-7 siswa. Setiap ruangan akan mendapatkan materi School Visit secara bergilir, meliputi: Murajaah Tahfidzul Quran bersama guru Tahfidz, motivasi perwalian atau curhat bersama wali kelas, atau kepala sekolah, motivasi tim kurikulum, sekaligus evaluasi, saran dan masukan siswa terhadap pembelajaran daring yang sudah berlangsung. Bisa ditambah problem solving terhadap kendala pembelajaran bersama guru mata pelajaran tertentu serta motivasi tim kesiswaan, mengarahkan siswa melakukan kegiatan yang positif dan terkendali walaupun orang tua mereka sudah kembali bekerja. Siswa yang belajar di rumah dan mengakses internet sangat rawan melakukan hal-hal yang kontradiktif terhadap tujuan pendidikan dan pembentukan akhlak mulia.

Pengorganisasian dan penyederhanaan kurikulum juga dilakukan dalam kegiatan School Visit. Waktu yang sangat terbatas, yaitu sejak pukul 08.3010.30 WIB harus dipergunakan seefektif dan seefisien mungkin agar tujuan kegiatan ini dapat tercapai. Tim kurikulum mengadakan rapat yang membahas materi yang diberikan ketika pelaksanaan school visit.

Adapun protokol kesehatan yang dijalankan selama di sekolah berdasarkan dokumen SMAIT Hidayah Klaten sebagai berikut (a) Orang tua sebagai mitra strategis dalam program school visit, orangtua/wali memastikan bahwa hanya siswa yang sehatlah yang berkunjung ke sekolah. Dengan menandatangani surat ijin berarti orangtua/wali ikut berperan aktif dalam kelancaran dan keselamatan anaknya. (b) Setiap siswa dalam pendampingan orangtua/wali wajib menyiapkan sarana prasaran proteksi pribadi dari rumah. Seperti masker, hand senitizer, jaket dan face shield serta makan minum yang dibutuhkan selama kunjungan di sekolah. (c) Perjalanan baik dari rumah ke 
sekolah dan kepulangan dari sekolah ke rumah harus ditempuh secara langsung, tanpa mampir-mampir ke tempat lain. (d) Siswa mengenakan masker dari rumah dan memakai face shield ketika mendekati gerbang sekolah. (e) Siswa di gerbang sekolah dicek suhu tubuh dengan thermogun oleh tim keamanan sekolah, jika suhu tubuh siswa melebihi 37.5 derajat celcius, maka siswa dipersilahkan pulang kembali dan tidak boleh masuk ke dalam komplek sekolah dan mengikuti school visit.(f) Siswa yang telah memenuhi ketentuan suhu badan, disuruh menunjukan surat ijin orangtua/ wali, lalu diijinkan masuk gerbang dengan tetap jaga jarak aman. (g) Siswa cuci tangan dengan sabun di wastafel yang ada di halaman lantai satu. (h) Siswa putra naik ke ruangan lewat tangga timur, siswa putri masuk lewat tangga barat. (i) Siswa mengisi absensi di lobi masing-masing tangga dan diarahkan ke ruangan masing-masing oleh petugas piket yang ditetapkan oleh sekolah. (j) Siswa duduk di kursi yang telah ditentukan (jaga jarak aman), tetap dengan memakai masker selama kegiatan School Visit berlangsung.

\section{Home Visit}

Home Visit adalah kegiatan kunjungan wali kelas dan guru ke rumah siswa yang sedang melakukan pembelajaran daring dengan ijin dan kesepakatan antara sekolah (dalam hal ini wali kelas/guru) dengan orang tua siswa. Home Visit ini ini didesain juga sebagai ajang silaturahmi, sarana sharing dan untuk memotivasi siswa bahkan bisa juga untuk ajang konsultasi pelajaran. Home Visit dilakukan dalam tiga gelombang, dimana setiap gelombang adalah selama 2 pekan. Selama durasi itu, wali kelas harus mengunjungi satu orang siswanya sesuai dengan prioritas yang telah ditetapkan yaitu: Prioritas pertama, siswa yang kesulitan mengikuti pembelajaran daring karena ketidak tersediaannya atau tidak memadainya fasilitas penunjang. Prioritas kedua, siswa yang dilaporkan mengalami penurunan motivasi dan semangat belajar karena efek BDR atau PJJ yang berkepanjangan dan Prioritas ketiga, bersifat tawaran kepada orangtua/wali siswa, siapa yang mau dikunjungi pihak sekolah dalam rangka silaturahmi, motivasi dan sharing.

Analisis terhadap pengorganisasian pembelajaran "Dar-Ling" di SMAIT Hidayah Klaten bahwa pembelajaran yang bervariasi dan bermakna bagi siswa akan mendorong tumbuhnya motivasi belajar, ini selaras dengan penelitian Suryana, 
$\mathrm{dkk}^{20}$. Pelibatan seluruh personal yang terlibat dalam proses pembelajaran akan menimbulkan rasa tanggungjawab dan menumbuhkan motivasi guru dalam proses pembelajaran. Dampak positif lainnya dengan adanya kombinasi pembelajaran daring dan luring ini akan menghilangkan kebosanan guru dan menghindarkan guru dari keterasingan di dunia luar karena terlalu lama mengajar dari dalam rumah ${ }^{21}$. Dari data pengorganisasian ini juga telah didapatkan berbagai macam aplikasi yang digunakan dalam pembelajaran daring yaitu Google Classroom ${ }^{22}$, aplikasi WhatsApp ${ }^{23}$. Aplikasi lain yang digunakan adalah Google Meet, Google Form, You Tube dan Website sekolah.

Pelaksanaan Home Visit diserahkan sepenuhnya oleh kepala sekolah kepada wali kelas, karena wali kelas paling tahu keadaan siswanya berdasarkan informasi yang mereka dapatkan dari para guru mapel maupun hasil penelusuran informasi pribadi wali kelas itu sendiri. Ketiga prioritas yang telah penulis paparkan di bagian perencanaan (siswa yang tidak memiliki perangkat BDR, siswa yang mengalami penurunan motivasi dan semangat belajar dan siswa yang ingin dikunjungi sekedar silaturahim, sharing dan curhat) menjadi acuan wali kelas untuk melakukan program Home Visit ini.

Bukti pelaksanaan Home Visit, guru/wali kelas yang bertugas diminta untuk mendokumentasikan kunjungan dan mengirimkannya kepada Kepala Sekolah/Waka kurikulum sebagai bukti verifikasi. Pengawasan yang dilakukan sekolah melalui angket dengan responden sebanyak 100 siswa untuk program School Visit menghasilkan data berikut ini: Kebermanfaatan School Visit bagi siswa sebanyak 95\% menyatakan bermanfaat, 4\% menyatakan kurang bermanfaat dan 1\% menyatakan tidak bermanfaat. School Visit mampu mengobati kerinduan siswa kepada sekolah dan guru: sebanyak 91\% mampu mengobati, 6\% kurang mengobati dan 3\% tidak mengobati kerinduan kepada sekolah dan guru. School Visit berperan dalam memotivasi siswa: 92\% menyatakan termotivasi, $6 \%$ kurang memotivasi dan $2 \%$ tidak memotivasi.

Sedangkan angket tentang Home Visit yang dilakukan kepada 15 siswa yang dikunjungi menghasilkan data berikut: Kebermanfaatan Home Visit bagi siswa sebanyak 100\% menyatakan bermanfaat dan 0\% menyatakan tidak bermanfaat. Home Visit mampu mengobati kerinduan siswa kepada sekolah

20 Yaya Suryana, Hary Sanusi Priatna, A. Heris Hermawan, "Manajemen Pembelajaran Daring Berbasis Empati Untuk Pemeliharaan Motivasi Belajar Daring Mahasiswa Dalam Situasi Wabah Covid19."

${ }^{21}$ R. Mastura, M., \& Santaria, “). Dampak Pandemi Covid-19 Terhadap Proses Pengajaran Bagi Guru Dan Siswa," Jurnal Studi Guru Dan Pembelajaran 3, no. 2 (2020): 289-95.

22 Iftakhar, "Google Classroom: What Works And How?"

23 So, "Mobile Instant Messaging Support for Teaching and Learning in Higher Education." 
dan guru: sebanyak 100\% mampu mengobati dan 0\% tidak mengobati kerinduan kepada sekolah dan guru. Home Visit berperan dalam memotivasi siswa: $100 \%$ menyatakan termotivasi dan $0 \%$ tidak memotivasi.

Analisis terhadap pengawasan pembelajaran semasa pandemi Covid-19 di SMAIT Hidayah Klaten menunjukkan bahwa kepala sekolah dan wakil kepala sekolah bidang kurikulum melakukan pengawasan dengan berbagai cara dan teknik untuk memastikan pembelajaran berjalan lancar seperti rencana. Teknik yang digunakan adalah observasi, wawancara, angket/kuesioner dan dokumentasi pelaksanaan tugas berupa photo di lokasi.

Data angket menunjukkan pengelolaan pembelajaran yang baik berdampak positif dan terbukti mempertahankan motivasi belajar siswa dan membangkitkan persepsi yang positif pada siswa selaras dengan pendapat Wena ${ }^{24}$. Hasil kajian terhadap pengawasan pembelajaran semakin menegaskan pernyataan Tutar bahwa dalam kondisi krisis para pemimpin -dalam kasus ini adalah kepala sekolah dan wakil kepala sekolah bidang kurikulum- dituntut untuk mendeteksi masalah ketika krisis terjadi, mengidentifikasi masalah dalam kerangka tujuan yang direncanakan, mengidentifikasi peluang yang paling praktis, mengevaluasi kegunaan resolusi guna membentuk resolusi akhir serta memantau tahapan-tahapan seperti implementasi resolusi. Tentunya pemimpin yang dimaksud di sini, sebagaimana dikatakan Sisman, M. ve Turan adalah pemimpin yang memiliki visi, pemimpin yang dibutuhkan dalam saat krisis adalah pemimpin yang optimis ${ }^{25}$.

Dari uraian di atas mengantarkan kepada suatu pemahaman bahwa pembelajaran di SMAIT Hidayah Klaten khususnya tentang manajemen pembelajaran selama masa pandemi Covid-19 sebagai berikut. Perencanaan (planning) pembelajaran di SMAIT Hidayah Klaten selama masa pandemi Covid-19 memadukan perencanaan pembelajaran dalam jaringan dan luar jaringan dengan konsep "Dar-Ling" yang bertumpu pada 3 prinsip yaitu Daring sebagai ekosistem, School Visit dan Home Visit.Pengorganisasian (Organizing) pembelajaran di SMAIT Hidayah Klaten selama masa pandemi Covid-19 dibagi menjadi dua bagian yaitu pembelajaran dalam jaringan/online dan pembelajaran luar jaringan/offline. Pembelajaran dalam jaringan terdiri atas pembelajaran daring dengan penyederhanaan kurikulum, mutabaah yaumiyah

${ }^{24}$ M Wena, Strategi Pembelajaran Inovatif Kontemporer: Suatu Tinjauan Konseptual Operasional (Jak: PT Bumi Aksara, 2011). . 35.

${ }^{25}$ M. Ibnu Ahmad, "Manajemen Krisis: Kepemimpinan Dalam Menghadapi Situasi Krisis Covid19," Leadership:Jurnal Mahasiswa Manajemen Pendidikan Islam 1, no. 2 (July 4, 2020): 223, https://doi.org/10.32478/leadership.v1i2.448. 
dan Tahfidzul Quran, bina pribadi Islami, pengembangan karakter dan skill. Pembelajaran luar jaringan terdiri atas School Visit dan Home Visit yang diorganisasikan sedemikian rupa dalam kendali wakil kepala kurikulum dan kepala sekolah. Penggerakan/Pelaksanaan (Actuating) pembelajaran di SMAIT Hidayah Klaten selama masa pandemi Covid-19 terdiri atas dua kegiatan utama yaitu pra kondisi dan penyiapan lembaga pendidikan agar bisa menerapkan pembelajaran "Dar-Ling" dengan baik, memenuhi protokol kesehatan selama pandemi Covid-19. Kegiatan utama yang kedua adalah pelaksanaan konsep "Dar-Ling" itu sendiri. Pengawasan (Controlling) pembelajaran di SMAIT Hidayah Klaten selama masa pandemi Covid-19 melibatkan pengelola lembaga pendidikan dan "pelanggan/costumer" lembaga pendidikan. Pengelola pendidikan yang dimaksud adalah pengawasan yang dilakukan oleh kepala sekolah dan wakil kepala sekolah bagian kurikulum kepada para guru yang telah diberikan tugas melaksanakan pembelajaran. "Pelanggan/Costumer" pendidikan adalah para siswa dan para orang tua/wali. Proses pengawasan ini menggunakan teknik bervariasi, antara lain pengamatan/observasi, wawancara dan angket.

Pembelajaran di sekolah mengalami penyederhanaan dan relaksasi kurikulum sebagaimana tertera dalam Surat Edaran Mendikbud nomor 4 tahun 2020, namun sampai hari ini sepengetahuan penulis belum ada kebijakan yang mengatur relaksasi standar penerimaan di perguruan tinggi. Pengelola SMAIT Hidayah Klaten hendaknya memikirkan cara agar kompetensi siswa yang sekarang duduk di kelas XII (12) dapat tercapai dengan maksimal agar dapat bersaing dalam seleksi masuk perguruan tinggi. Penyederhanaan kurikulum dan pengurangan penugasan yang dilakukan sekolah, secara berkala perlu untuk disesuaikan dengan kondisi terkini. Masa Adaptasi Kebiasaaan Baru (New Normal) memungkinkan siswa untuk belajar lebih lama dan diberikan penugasan yang lebih dari biasanya, tentunya dengan mempertimbangkan banyak faktor. Hal ini penting untuk memberikan iklim belajar di rumah, dari pada siswa keluar rumah dan melakukan aktifitas yang kontraproduktif terhadap tujuan pendidikan.

\section{KESIMPULAN}

Pembelajaran di masa pandemi mengharuskan sekolah mengambil keputusan kreatif dan inovatif dalam menghadapi perkembangan yang ada. SMAIT Hidayah Klaten sangat adaptif terhadap kebijakan pemerintah terkait proses pembelajaran di masa Covid-19. Setidaknya, uraian diatas mengantarkan kepada temuan penelitian bahwa kreasi 
manajemen pembelajaran menggunakan strategi pembelajaran dalam jaringan dan pembelajaran luar jaringan yang kemudian konsep ini diberi nama "DAR-LING". Konsep ini bertumpu pada 3 prinsip yaitu daring sebagai ekosistem, school visit dan home visit. Kegiatan home visit dengan rentang waktu 2 pekan menurut data yang penulis dapatkan terlaksana untuk 3 orang siswa setiap kelas, jika jumlah siswa di dalam kelas 26 siswa maka akan membutuhkan waktu 4.5 bulan untuk setiap siswa mendapat kunjungan 1 kali selama periode satu semester. Sekolah hendaknya memikirkan intensitas kunjungan yang lebih dari satu kali untuk siswa yang mengalami kesulitan belajar baik karena ketiadaan fasilitas, penurunan motivasi dan semangat belajar dan hal lainnya. Pembaruan/Updating data pelaksanaan dan pengawasan serta evaluasi pembelajaran selama masa pandemi Covid-19 hendaknya dilakukan secara berkala. Data ini penting sebagai dasar pemimpin lembaga pendidikan untuk pengambilan keputusan alternatif pembelajaran yang akan dilakukan. Data yang lengkap, akurat dan terverifikasi kebenarannya akan menjadikan kebijakan yang diambil juga akan tepat.

\section{DAFTAR PUSTAKA}

Ahmad, M. Ibnu. "Manajemen Krisis: Kepemimpinan Dalam Menghadapi Situasi Krisis Covid-19." Leadership:Jurnal Mahasiswa Manajemen Pendidikan Islam 1, no. 2 (July 4, 2020): 223. https://doi.org/10.32478/leadership.v1i2.448.

Aji R. "Dampak Covid-19 Pada Pendidikan Di Indonesia: Sekolah, Keterampilan, Dan Proses Pembelajaran." SALAM: Jurnal Sosial Dan Budaya Syar-I 7, no. 5 (April 14, 2020): 395-402.

Arifa, Fieka Nurul. Tantangan Pelaksanaan Kebijakan Belajar Dari Rumah Dalam Masa Darurat Covid-19. Jakarta: Pusat Penelitian Badan Keahlian. DPR RI, 2020.

Dewi, Wahyu Aji Fatma. "Dampak COVID-19 Terhadap Implementasi Pembelajaran Daring Di Sekolah Dasar." EDUKATIF : JURNAL ILMU PENDIDIKAN 2, no. 1 (April 29, 2020): 55-61. https://doi.org/10.31004/edukatif.v2i1.89.

Enriquez, M. A. S. "Students Perceptions on the Effectiveness of the Use of Edmodo as a Supplementary Tool for Learning." In DLSU Research Congress, 2014.

Iftakhar, S. "Google Classroom: What Works And How?" Journal of Education and Social Sciences, 2016.

Joyce, B., Weil, M., \& Calhoun, E. Models of Teaching: Model-Model Pengajaran. Edited by Ahmad Fawaid dan Ateilla Mirza. Yogyakarta: Pustaka Pelajar, 2009.

Khasanah, D. R. A. U., Pramudibyanto, H., \& Widuroyekti, B. "Pendidikan Dalam Masa Pandemi Covid-19.” . . Jurnal Sinestesia 10, no. 1 (2020): 41-48.

"KPAI Terima 213 Aduan Soal Pembelajaran Jarak Jauh," n.d. https://republika.co.id/berita/q8q6oq354/kpai-terima-213-aduan-soalpembelajaran-jarak-jauh. . 
Kumar, Vikas, and Pooja Nanda. "Social Media in Higher Education." International Journal of Information and Communication Technology Education 15, no. 1 (January 2019): 97-108. https://doi.org/10.4018/IJICTE.2019010107.

Mahmud. “Sosiologi Pendidikan.” Bandung: Pustaka Setia, 2012.

Mastura, M., \& Santaria, R. "). Dampak Pandemi Covid-19 Terhadap Proses Pengajaran Bagi Guru Dan Siswa." Jurnal Studi Guru Dan Pembelajaran 3, no. 2 (2020): 28995.

Moore, Joi L., Camille Dickson-Deane, and Krista Galyen. “E-Learning, Online Learning, and Distance Learning Environments: Are They the Same?" The Internet and Higher Education 14, no. 2 (March 2011): 129-35. https://doi.org/10.1016/j.iheduc.2010.10.001.

Murfi, Ali, Irwan Fathurrochman, Atika Atika, and Nora Saiva Jannana. "Kepemimpinan Sekolah Dalam Situasi Krisis Covid-19 Di Indonesia." MANAGERIA: Jurnal Manajemen Pendidikan Islam 5, no. 1 (June 4, 2020): 119-36. https://doi.org/10.14421/manageria.2020.51-07.

"Reported Cases and Deaths by Country, Territory, or Conveyance," n.d. https://www.worldometers.info/coronavirus/ .

Satuan Tugas Penanganan COVID-19. “Situasi Virus COVID-19 Di Indonesia," n.d. https://covid19.go.id.

Sicat, A. S. "Enhancing College Students Proficiency in Business Writing Via Schoology." International Journal of Education and Research, 2015.

So, Simon. "Mobile Instant Messaging Support for Teaching and Learning in Higher Education." The Internet and Higher Education 31 (October 2016): 32-42. https://doi.org/10.1016/j.iheduc.2016.06.001.

Wena, M. Strategi Pembelajaran Inovatif Kontemporer: Suatu Tinjauan Konseptual Operasional. Jak: PT Bumi Aksara, 2011.

Wijaya A. "Students Responses Toward The Use Of Whatsapp In Learning." Teaching and Learning English in Multicultural Contexts (TLEMC) 2, no. 1 (2018).

Xian Zhou, Jingkang Zhu \& Tao Xu. "Clinical Characteristics of Coronavirus Disease 2019 (COVID-19) Patients with Hypertension on Renin-Angiotensin System Inhibitors." Clinical and Experimental Hypertension 42, no. 7 (2020): 656-60. https://doi.org/10.1080/10641963.2020.1764018.

Yaya Suryana, Hary Sanusi Priatna, A. Heris Hermawan, Wahyu Hidayat. "Manajemen Pembelajaran Daring Berbasis Empati Untuk Pemeliharaan Motivasi Belajar Daring Mahasiswa Dalam Situasi Wabah Covid-19." In Penulisan Karya Tulis Ilmiah UIN Sunan Gunung Djati Bandung Di Masa Work From Home Tahun 2020, 2020.

http://digilib.uinsgd.ac.id/view/creators/Sanusi=3AHary_Priatna=3A=3A.html .

Zapalska A, Brozik D. Learning Styles and Online Education, 2006. 